\title{
STRENGTHENING SOCIETAL RESILIENCE DURING COVID-19 PANDEMIC
}

DOI: 10.36740/WLek202105117

\author{
Andriana M. Kostenko, Nina D. Svitailo, Mykola S. Nazarov, Viktoriya S. Kurochkina, Yevhen V. Smiianov
}

SUMY STATE UNIVERSITY, SUMY, UKRAINE

\begin{abstract}
The aim: To investigate factors that can negatively affect societal resilience in the context of the COVID-19 pandemic and identify communication aspects of strengthening resilience through information policy formation.

Materials and methods: In the research process, the authors employed the monographic and abstract-logical methods. The communication aspect analysis of strengthening social resilience in the context of the COVID-19 pandemic also grounded upon the results of the authors' sociological study "Motivation of compliance/non-compliance with quarantine restrictions by the population of Ukraine". Focus-group interviews and surveys. A total of 1,700 respondents represent the adult population of Ukraine aged 18 and older (except those living on the territory temporarily not controlled by the Ukrainian authorities - the Autonomous Republic of Crimea, some areas of Donetsk and Luhansk regions). The error of the study representativeness with a probability of 0.95 : does not exceed $4 \%$.

Results: The analysis results indicate that under pandemic conditions informational space of Ukraine is charging with low-quality and diverse information and is getting out of control, which entails adverse effects on societal resilience. Besides, a survey conducted by the SSU Center for Social Studies endorses the availability of communication gaps. The poll claims $38.6 \%$ of Ukrainians to be dissatisfied with their awareness level of Covid-19 because the information is contradictory and unreliable. The opinion poll also proves the low level of Ukrainians' trust in state institutions and official details on the Covid-19 pandemic. Furthermore, violations of quarantine restrictions are socially acceptable, and a significant part of the population tends to ignore such violations by others. That is, among Ukrainians, compliance with quarantine restrictions has not become a social norm. Conclusions: An essential component for molding social resilience is the development and adoption of communication policies to change human behavior in the long-term in the context of the COVID-19 pandemic. The government should also develop a Public Health Awareness Concept in the pandemic with appropriate implementation plans at the state, regional and territorial community levels.
\end{abstract}

KEY WORDS: healthcare institutions, societal resilience, COVID-19, communication, civil society

Wiad Lek. 2021;74(5):1137-1141

\section{INTRODUCTION}

Amid turbulence and economic crisis caused by the COVID-19 pandemic, states have to revise their development forecasts, approaches to implementing social or economic policy, and look for new societal resilience management models at both national and local levels.

Social (or societal) resilience is an integral part of national stability. It is defined as a nation-state preserving ability regarding its societal cohesion when confronted by external and internal stresses caused by socio-political changes and/ or violent disturbance [1]. By resilience, we mean a society's ability to resist and recover from crises and perturbations easily and quickly, the ability to develop or adapt to drastic and potentially long-term changes. Moreover, the changes themselves can give rise to new norms. In this case, societal resilience should envisage new rules rather than resist them [2].

The formation of social resilience requires not only taking measures from the state but also social capability. The ongoing Ukrainian society development stage implies additional challenges because the characteristic confrontation between the government and civil society in the pandemic has intensified dramatically. Simultaneously, the lack of communication strategy capable of minimizing risks and shaping the necessary community cohesion in the face of everyday challenges has become even more pronounced. The media actively broadcasts the message of insufficient responsibility of the population, constant violations of quarantine requirements, regarded by the government and health authorities as one of the main factors determining the critical dynamics of the disease expansion and the similar critical situation in hospitals. Along with this, citizens do not trust the official information about COVID-19 too much. The critical distrust in the government exacerbates the problem at all levels, which results in the unwillingness to comply with quarantine restrictions. In this situation, state policy relating to vaccination or applying restrictive measures is complicated by the lack of a systematic communication policy to build social resilience in the face of uncertainty about the coronavirus pandemic.

\section{THE AIM}

To analyze the factors that can negatively affect societal resilience in the pandemic and identify communication aspects of strengthening resilience through information policy molding. 
The practical significance of the results. This study's main provisions can be used to form a model for developing communication strategies to strengthen social capital and create social resilience in Ukraine.

\section{MATERIALS AND METHODS}

The study used a monographic method (analysis of Ukrainian and foreign scientific achievements on social resilience and social capital development problems) and an abstract-logical method (theoretical generalizations and formulation of conclusions). The analysis of communication aspects of strengthening social resilience under the COVID-19 pandemic was also carried out based on the results of the authors' sociological study "Motivation of compliance/non-compliance with quarantine restrictions by the population of Ukraine".

An all-Ukrainian sociological study was conducted in late 2020 by the Center for Social Studies of Sumy State University [3]. Methods: focus-group interviews and questionnaires (surveys). A total of 1,700 respondents representing the adult population of Ukraine aged 18 and older (except for those living on the territory temporarily not controlled by the Ukrainian authorities - the Autonomous Republic of Crimea, some areas of Donetsk and Luhansk regions). The error of the study representativeness with a probability of 0.95 : does not exceed $4 \%$.

Quota sampling: quotas by sex, age, region, size of the settlement. Respondents were randomly selected in four clusters of Ukraine: Western, Central, Southern, and North-Eastern. A specially designed questionnaire was used as a tool, formed in light of the focus-group study results conducted at the previous stage.

\section{RESULTS}

Violation of quarantine restrictions by the population is one of the threats that can worsen the epidemiological and, consequently, the country's socio-economic situation. Studies by Paola Giuliano and Imran Rasul [4] confirm that social capital, the level of trust in government and institutions, and media sources used by the population are essential in quarantine compliance. We believe that these are decisive factors in the formation of societal resilience as well. Therefore, let us analyze the specified characteristics of social stability and determine the communication aspects of strengthening resilience in the Covid-19 pandemic.

Under social capital, scholars understand "networks, shared norms, values, and insights that facilitate collaboration within or among groups" of the population [5]. Recognizing social capital as one of the elements of interaction between society and state institutions, which determines a country's development level and positioning at the international level [6], researchers pinpoint the importance of active and conscious construction of such interaction in society [7-9].

It is the system of broad and reliable informing citizens on fundamental processes taking place in society, govern- ment and self-government activity, and the public sector that plays a decisive role in building such interaction, formed on the basis of shared norms and values.

It is just about the systematic nature of such information, which should be based not only on relevant institutions such as independent media or select communication channels. With their help, the government distributes required information, the legislative framework for freedom of expression, etc. There should also be an appropriate level of trust in such sources and public confidence in the government, which is also one of the conditions for information security and social resilience.

It is worth highlighting that through social networks, accepted social norms, and trust, it is social capital that creates conditions for cooperation and collaboration between different actors, whose benefit obtains everyone. And the lack of such trust and partnership is characteristic not only of the Ukrainian society [10].

The crises generate a complete consolidation of the human and social factors in developed countries. They are a catalyst for deepening the social situation in the countries with economies in transition. At the same time, we can expect that the crisis brought on by the pandemic is capable of activating social movements to overcome the common problem. However, it contributes to the relocation of communications into the virtual environment [11].

However, the existing drawbacks in communication between the authorities and society and close to critical mistrust level in state institutions and information emanating from them will hamper such activation. And this is in a situation where a large part of the population needs help and support, including due to the loss of previously common forms of communication that have become less accessible under quarantine restrictions.

Between 2016 and 2018, the International Centre for Defense and Security (ICDS) conducted "Resilient Ukraine," a project regarding civil society and national security [12]. It combined field research (survey) and analytical work regarding legislation and government action plans in national security, statistical data representations, etc.

The survey's results and the analysis of Ukrainian legislation and government action plans in the field of community resilience and communications help us identify the main gaps between state institutions and civil society due to an excessively centralized system of power taking place in Ukraine for decades. As a result, the financial, symbolic, and other resources are concentrated in Kyiv and are constantly exhausted from the regions. In turn, regions do not receive enough economic and social capital to implement their functions completely. One of the main gaps between healthcare institutions and citizens is a communication gap.

The pandemic spread exacerbated the situation even more because of the threat to your own and your relatives' health and lives, the state of uncertainty and insecurity caused by the disease unpredictability, and the limitation of traditional in Ukraine contacts with relatives, friends, and colleagues due to quarantine. It aroused increased interest in the information capable of clarifying the situation, suggesting 


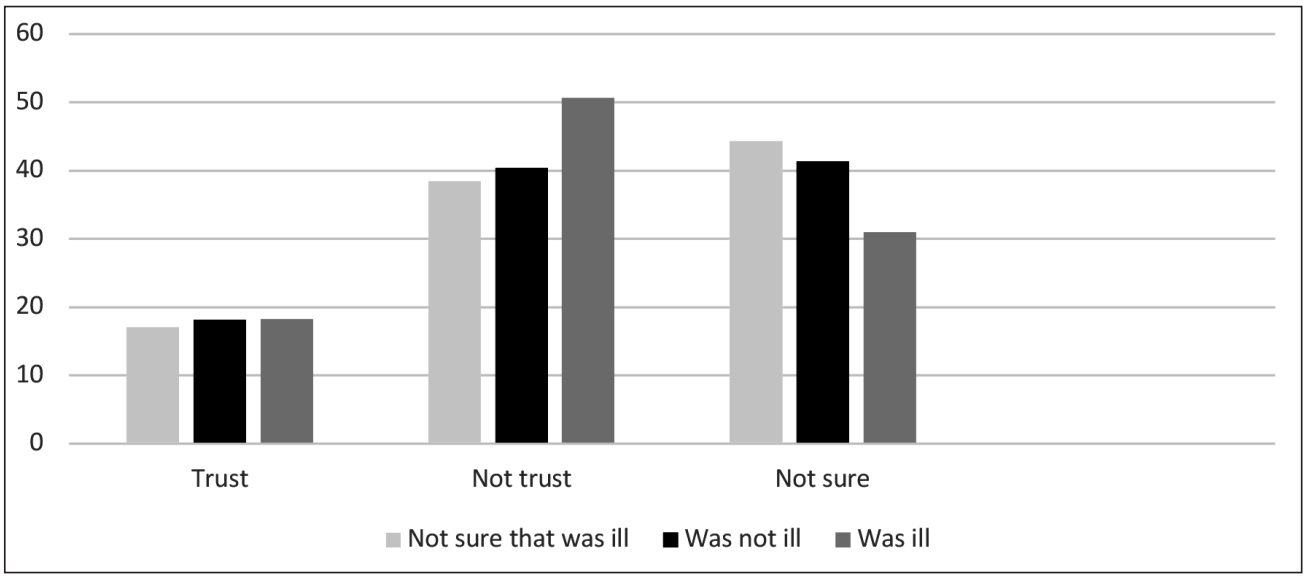

Fig. 1. How do you feel about the official information on the number of infected and the severity of the disease?

Table 1. Do you have enough or not enough information on Covid-19?

\begin{tabular}{ccccc}
\hline & $\begin{array}{c}\text { There is enough } \\
\text { information and it } \\
\text { is easy to find it; }\end{array}$ & $\begin{array}{c}\text { More information is } \\
\text { needed - official and } \\
\text { with clear instructions; }\end{array}$ & $\begin{array}{c}\text { There is a lot of information, } \\
\text { but it is contradictory and } \\
\text { unreliable; }\end{array}$ & $\begin{array}{c}\text { I am not interested and do } \\
\text { not believe anyone knows } \\
\text { something reliable. }\end{array}$ \\
\hline $18-29$ yrs. & 44 & 12.2 & 36.1 & 7.7 \\
\hline $30-39$ yrs. & 32.5 & 19.6 & 40.8 & 7.2 \\
\hline $40-49$ yrs. & 31.6 & 19.8 & 41.8 & 6.8 \\
\hline 50 yrs. \& older & 36.3 & 23.5 & 36.3 & 3.9 \\
\hline
\end{tabular}

behavioral options to prevent infection or an action algorithm in case of illness. Thus, the situation required both a substantive content of an informational environment and a certain reformatting of the information sources themselves. Such reformatting in the pandemic has become a real threat to societal resilience, as vital sources of official information became unclaimed by a significant part of the population due to low trust. And more accessible social networks with a full range of diverse and not always reliable information have come to the forefront. The other influential actors are emerging in the information system - namely, family doctors, bloggers creating topical talk shows on all channels and quite freely interpreting the socio-medical problems of Covid-19 and possible options on economic development, policy, and even global perspectives. Thus, the country information space, which is clearly in a crisis, is filled with low-quality, diverse information. It is getting out of control, which cannot help affecting social stability.

Communication gaps are also confirmed by a survey conducted by the SSU Center for Social Studies, according to which $38.6 \%$ of Ukrainians claim that against the background of information space overloading with reports of Covid-19, they are dissatisfied with their level of awareness, as information is contradictory and unreliable. Another $19.1 \%$ of respondents say that they need more information - official and with clear instructions. Personal experience of COVID-19 (own or relatives ' disease) also affects the level of awareness. After all, respondents who have not been ill with Covid-19 or are unsure whether they had it or not are more likely to doubt the information accuracy. The older the respondents, the more often they note the need for official information with clear instructions (Table 1) [3].
Thus, the results have concluded that a significant part of the population - by their estimates - lives in an information-poor setting and receives contradictory, misleading, and misinforming information. About $40 \%$ of respondents say about information redundancy. This situation is called "infodemic" - an overload of information and fake news. It is aimed at people to provoke actions and reactions that could contribute to potential destabilization. Naturally, infodemic undermines trust in governments and government institutions.

Several studies show that people's trust in governments and institutions affects their willingness to comply with emergency public health measures [13].

As noted, the degree of trust in government and institutions is an essential prerequisite for forming societal resilience [14]. According to the research results, there is a crisis of legitimacy in Ukraine. The level of trust in state institutions is one of the lowest in Europe. Thus, based on a study conducted in late 2020 by the Razumkov Centre's sociological laboratory, Ukrainians have the least trust in the Government of Ukraine, the state apparatus in general, the Verkhovna Rada of Ukraine, anti-corruption bodies, and the judicial system [15].

We observe similar distrust tendencies regarding the attitude to official information about the pandemic [3]. In particular, Ukrainians do not trust too much the official information about the number of infected people and the severity of the disease $(42.1 \%)$, and another $40 \%$ are not sure whether it is worth trusting or not. Moreover, the respondents who had been ill more often expressed distrust in the official information $50.7 \%$ among those who had been sick against $40.4 \%$ who did not get ill and 
$38.5 \%$ who are not sure whether they were unwell or not) (Figure 1).

We can track the correlation between the low level of communication with the population and the unpreparedness to adhere to quarantine restrictions. After all, one of the significant reasons, which from the respondents' viewpoint explains the reluctance of people to comply with quarantine restrictions, is incomprehension of such restrictions logic (27.8\%). Another 21.2\% believe that people violate quarantine because others do. Also, 20.8\% do not consider quarantine restrictions efficient.

\section{DISCUSSION}

In this context, we can talk both about the quality of the information provided by official sources, its clarity and accessibility for different groups of the population, and a certain degree of bias in information consumers themselves, who are in advance sure of its partiality or unprofessionalism. After all, the above tier of distrust raises doubts about the specialists' competence. People cannot be experts either - for example, about the practicality of restrictions and their effectiveness.

The low level of public trust in each other, not only in the state and the media, can also be considered quite critical for the development of social capital and societal resilience in general. Respondents note that they are not ready to comply with quarantine restrictions because they are not sure that others will do so. Thus, $47.2 \%$ see the reason for people's unwillingness to observe quarantine restrictions in their irresponsibility, which can be considered a demonstration of the high level of distrust in other people.

People tend to react cautiously to quarantine violations by others, mainly move away from danger $(54.3 \%)$ or do not respond in any way (18.1\%), testifying their unpreparedness for public dialogue, being relevant today. An insignificant part of Ukrainians responds to violators, in particular, by making remarks to them $(24.7 \%)$.

The indicators of "indifference" to quarantine violations are noteworthy. The most pronounced of them are among the respondents in the younger age group $-28.1 \%$. At the same time, the older the respondents, the less often they mention this position. The percentage of those who make remarks in case of quarantine violation, respectively, grows with the age of respondents.

Thus, we can argue that compliance with quarantine restrictions has not become a social norm among Ukrainians. Therefore, one should not expect mass voluntary and conscious behavior of the population towards the observance of quarantine restrictions. And in the absence of the specified social norm, the only mechanism for controlling the epidemiological situation is the strengthening of formal forcing by the state. Along with this, a crucial component of social resilience is the development of information policy in the pandemic, aimed at creating norms of social responsibility that would ensure the implementation of coercion through social pressure.

\section{CONCLUSIONS}

Molding societal resilience requires not only measures from the state but also social capability. However, during the pandemic in Ukraine, there is a confrontation between the government and civil society. The analysis results indicate a low level of Ukrainians' trust in state institutions and official information about the Covid-19 pandemic. Furthermore, quarantine violations are socially acceptable, and a significant part of the population tends to ignore such violations from others. That is, compliance with quarantine restrictions among Ukrainians has not become a social norm. Therefore, in the absence of voluntary and conscious behavior of the population towards observing quarantine, the formal state coercion remains the only mechanism.

An indispensable component of social resilience is developing and adopting communication policies to change human behavior in the long-term under the Covid-19 pandemic. In particular, the government should envisage the advancement of a Public Health Awareness Concept in the pandemic (from now on the Concept) with appropriate implementation plans (at the state, regional and territorial community level). The Concept goal is supposed to become a comprehensive informing of Ukrainian citizens on minimizing the risks of getting sick, protecting and maintaining mental health, developing social ties that will build trust between government, local self-government, and citizens.

\section{REFERENCES}

1. Jackson S., Ferris T.L.J. Infrastructure resilience: past, present, and future. George Mason University Magazine. 2012; 1-4.

2. Calvin Ch., Dong Q., Tan F.. Smart Community and Social Resilience: Reflection on the COVID-19 Pandemic DOI: 10.24251/HICSS.2021.300.

3. Zvit za rezultatamy sociologichnogo opytuvannya "Motyvaciya dotrymannya/nedotrymannya naselennyam Ukrayiny karantynnyx obmezhen". [Report on results of sociological survey "Motivation for keeping/not keeping of quarantine measures by population of Ukraine"]. Sumy: SumDU. 2021; 53. https://essuir.sumdu.edu.ua/ handle/123456789/82443. (in Ukrainian).

4. Giuliano P., Rasul I. Compliance with social distancing during the Covid-19 crisis. https://voxeu.org/article/compliance-social-distancingduring-covid-19-crisis.

5. Scrivens K. Smith C. Four Interpretations of Social Capital: An Agenda for Measurement. OECD Statistics Working Papers. 2012. http:// www.oecd-ilibrary.org/economics/four-interpretations-of-socialcapital_5jzbcx010wmt-en.

6. Ruda T.V., Nagorichna O.S. Teoretychni aspekty formuvannya socialnogo kapitalu v Ukrayini. [Theoretical aspects of social capital formation in Ukraine]. Innovacijna ekonomika. 2020; 3-4: 120-126. (in Ukrainian).

7. Sybyryakov S. 0. Komunikatyvni praktyky u derzhavnomu upravlinni v konteksti rozvytku informacijnogo suspilstva. Publichne upravlinnya: teoriya i praktyka : zbirnyk naukovyx pracz Asociaciyi doktoriv nauk $z$ derzhavnogo upravlinnya. [Communicational practices in state policies by development of informational society. Public management: theory and practice: collection of studies by State management DSC Association]. Kharkiv: «DouNaukDerzhUpr». 2010; 3-4: 112-119. (in Ukrainian). 
8. Sybyryakov S. Socialni media yak seredovyshhe arhetypnogo vplyvu na masovu svidomist. Publichne upravlinnya: teoriya i praktyka : zbirnyk naukovyx pracz Asociaciyi doktoriv nauk z derzhavnogo upravlinnya. [Social media as medium for archetypic impact on publics mind. Public management: theory and practice: collection of studies by State management DSc Association]. Kharkiv: «DouNaukDerzhUpr». 2013; 1 (13): 202-210. (in Ukrainian).

9. Sybyryakov S. 0. Socialnyj kapital derzhavnyx sluzhbovciv Ukrayiny yak chynnyk stanovlennya gromadyanskogo suspilstva [Social capital of state officials of Ukraine as a factor of public society establishment]. Derzhavne upravlinnya: udoskonalennya ta rozvy tok. 2013; 4. http:// nbuv.gov.ua/UJRN/Duur_2013_4_8. (in Ukrainian).

10. Garrido S. Plenty of trust, not much cooperation: Social capital and collective action in early twentieth century eastern Spain. European Review of Economic History. 2014; 18(4): 413-432.

11. Ruda T. V. Socialnyj kapital yak element zabezpechennya nacionalnoyi bezpeky [Social capital as an element of providing national safety]. https://www.ndifp.com/1374/ (in Ukrainian).

12. Teperik D., Jermalavičius T., Senkiv G. et al. A Route to National Resilience. Building. Whole-of-Society Security in Ukraine. 2018. https:// uploads.icds.ee/ICDS_Report_A_Route_to_National_ResilienceBuilding-Whole-of-Society_Security_in_Ukraine_April_2018.pdf.

13. Brück T., Ferguson N., Justino P. Stojetz W. Trust in the time of corona. doi.org/10.35188/UNU-WIDER/2020/839-9.

14. Kleinfeld R. Do Authoritarian or Democratic Countries Handle Pandemics Better? https://cutt.ly/jlBll93.

15. Razumkov Center. Ocinka gromadyanamy sytuaciyi v krayini, riven doviry do socialnyx instytutiv ta politykiv, elektoralni oriyentaciyi gromadyan (zhovten-lystopad 2020r.) [Assessment of state public situation, level of trust to social establishments and policy, electoral orientation of population (Oct-Nov 2020)]. https://razumkov.org.ua/napriamky/ sotsiologichni-doslidzhennia/otsinka-gromadianamy-sytuatsii-vkraini-riven-doviry-do-sotsialnykh-instytutiv-ta-politykiv-elektoralnioriientatsii-gromadian-zhovten-lystopad-2020r. (in Ukrainian).
ORCID and contributionhip:

Vladyslav A. Smiianov: 0000-0002-4240-5968 A,D,E

Andriana M. Kostenko: 0000-0002-8970-4244 ${ }^{\text {B,C,D,F }}$

Nina D. Svitailo: 0000-0002-4944-1064 ${ }^{A, D, E}$

Mykola S. Nazarov: 0000-0002-4504-7908 A,D,E

Viktoriya S. Kurochkina: 0000-0003-3325-0527 D,F

\section{Conflict of interest:}

The Authors declare no conflict of interest.

\section{CORRESPONDING AUTHOR}

Andriana M. Kostenko

Sumy State University

2 Rymskogo-Korsakova st., 40007 Sumy, Ukraine

tel: +380509741149

e-mail:kostenkopr@ukr.net

Received: 08.01.2021

Accepted: 31.03 .2021

A - Work concept and design, B - Data collection and analysis, C - Responsibility for statistical analysis, D-Writing the article, $\mathbf{E}$-Critical review, $\mathbf{F}$ - Final approval of the article 